\title{
Experimental Organism Benign Epithelial Stromal Tumor
}

National Cancer Institute

\section{Source}

National Cancer Institute. Experimental Organism Benign Epithelial Stromal Tumor. NCI

Thesaurus. Code C124609.

A benign neoplasm containing two or more cell types arising from the mesenchymal and epithelial components. 